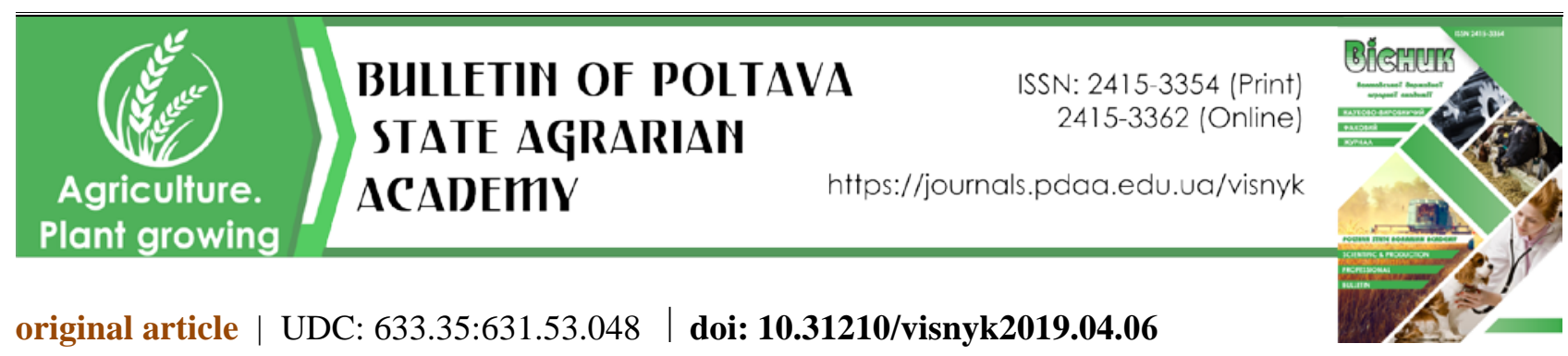

INFLUENCE OF PEA SOWING RATES ON STRUCTURAL ELEMENTS AND GRAIN YIELDS

V. V. Lykhochvor,

ORCID ID: 0000-0003-0377-6157, E-mail: LYKHOCHVOR@ukr.net,

M. O. Andrushko,

ORCID ID: 0000-0002-4099-7605, E-mail: andrushko.mykola@eridon.ua,

Lviv National Agrarian University, 1, Volodymyra Velykoho str., Dubliany, Zhovkva district, Lviv region, 80381, Ukraine

High yields of pea grain can be obtained by growing it using intensive technology with applying calculated rates of mineral fertilizers and integral application of plant protection means. It is also important to optimize the sowing rates of pea seeds in certain soil-climatic conditions. The aim of the study was to determine the effect of six sowing rates $(0.9 ; 1.0 ; 1.1 ; 1.2 ; 1.3 ; 1.4$ million/ha) on the indices of yield structure and grain productivity of Madonna pea variety. During the research the following methods were used: field, quantitative, method of test sheaf, weight, statistical. The results of the conducted studies have shown that changing the density of agro-phytocenosis affects the pea yield, which is explained by the formation of different indicators of the crop structure. It was found that increasing the sowing rate from $0.9 \mathrm{million} / \mathrm{ha}$ to $1.4 \mathrm{million} / \mathrm{ha}$ led to the increase of plant density before harvesting from $70 \mathrm{pcs} / \mathrm{m}^{2}$ to $90 \mathrm{pcs} / \mathrm{m}^{2}$, or by $20 \mathrm{pcs} / \mathrm{m}^{2}$. However, this did not ensure the expected yield increase, since the individual productivity of the pea plants decreased in the densely sown areas. It was revealed that sowing rates significantly affected the structure of pea yield. As the seed sowing rate increased from $0.9 \mathrm{million} / \mathrm{ha}$ to $1.4 \mathrm{million} / \mathrm{ha}$, the number of pods per plant decreased from 4.8 to 4.5 pcs, the number of grains in a pod - from 6.9 to 6.1 pcs, and the number of grains per plant - from 33 to 27.6 pcs. The main element of productivity, grain weight per plant decreased in densely sown areas from $9.60 \mathrm{~g}$ in the variant with the sowing rate of 0.9 million/ha to $7.05 \mathrm{~g}$ at sowing rate of 1.4 million/ha, i.e. by $2.55 \mathrm{~g}$. Increasing the sowing rate was also accompanied by decreasing the weight of 1000 grains, from $291.0 \mathrm{~g}$ to $255.8 \mathrm{~g}$, respectively. The optimal sowing rate of Madonna pea variety under sufficient and excessive moistening (in 2017 the rainfall was $761 \mathrm{~mm}$, in $2018-818 \mathrm{~mm}$, and in $2019-803 \mathrm{~mm}$ ) of the Western Forest-Steppe of Ukraine is 1.0 and $1.1 \mathrm{million} / \mathrm{ha}$., The grain yield in these variants was the highest, amounting to $6.52 \mathrm{t} / \mathrm{ha}$ and $6.55 \mathrm{t} / \mathrm{ha}$. Such level of yield was obtained as a result of the rational combination of plant density before harvesting (77 and $\left.82 \mathrm{pcs} / \mathrm{m}^{2}\right)$ and the increase of grain weight per plant to $8.96 \mathrm{~g}$ and $8.51 \mathrm{~g}$. The increase and decrease of sowing rate over 1.0 and $1.1 \mathrm{mil}-$ lion / ha causes yield decreasing.

Key words: pea, sowing rates, structural elements, yield.

\title{
ВПЛИВ НОРМ ВИСІВУ ГОРОХУ НА ЕЛЕМЕНТИ СТРУКТУРИ ТА ВРОЖАЙНІСТЬ ЗЕРНА
}

\section{В. В. Лихочвор, М. О. Андрушко,}

Львівський національний аграрний університет, м. Дубляни, Україна

Високу врожайність зерна гороху можна одержати при вирощуванні його за інтенсивною технологією з внесенням розрахункових норм мінеральних добрив та інтегральним застосуванням засобів захисту рослин. Актуальним є також оптимізація норм висіву насіння гороху в певних трунтовокліматичних умовах. Метою досліджень було встановити вплив шести норм висіву (0,9; 1,0; 1,1; 1,2; 1,3; 1,4 млн/га) на показники структури врожаю та зернову продуктивність гороху сорту Мадонна. $У$ 


\section{СІЛЬСЬКЕ ГОСПОДАРСТВО. РОСЛИННИЦТВО}

процесі досліджень використано такі методи: польовий, кількісний, метод пробного снопа, ваговий, статистичний. Результати проведених досліджень показали, щуо зміна густоти агрофітоценозу впливає на врожайність гороху, щзо пояснюється формуванням різних показників структури врожаю. Встановлено, щуо підвищення норми висіву з 0,9 млн/га до 1,4 млн/га призвело до збільшення густоти рослин перед збиранням з $70 \mathrm{~mm} / \mathrm{m}^{2}$ до $90 \mathrm{um} / \mathrm{m}^{2}$, або на $20 \mathrm{~mm} / \mathrm{m}^{2}$. Проте це не забезпечило очікуваного збільшення врожайності, оскільки в загущених посівах зменшилась індивідуальна продуктивність рослин гороху. Виявлено, щзо норми висіву мали істотний вплив на показники структури врожаю гороху. При зростанні норми висіву насіння з 0,9 млн/га до 1,4 млн/га кількість бобів на рослині зменшилась 3 4,8 до 4,5 шт., кількість зерен у бобі з 6,9 до 6,1 шт., кількість зерен з рослини з 33 до 27,6 шт. Основний елемент продуктивності, маса зерна з рослини знизилася при загущенні посівів з 9,60 г на варіанті з висівом 0,9 млн/га до 7,05 г за висіву 1,4 млн/га, тобто на 2,55 г. Збільшення норми висіву супроводжувалося також зниженням маси 1000 зерен, відповідно з 291,0 г до 255,8 г. Оптимальною нормою висіву гороху сорту Мадонна в умовах достатнього й надмірного зволоження (сума опадів 2017 р. була 761 мм, 2018 р. -818 мм, 2019 р. - 803 мм) західного Лісостепу України є 1,0 та 1,1 млн/га. На изи варіантах урожайність зерна була найвищою $і$ становила 6,52 m/2a ma 6,55 m/2а. Такий рівень урожайності одержано внаслідок раџіонального поєднання густоти рослин перед збиранням (77 та $82 \mathrm{um} . / \mathrm{m}^{2}$ ) та підвищення показника маси зерна з однієї рослини до 8,96 г та 8,51 г. 3більшення $i$ зменшення норми висіву понад 1,0 і 1,1 млн/га спричинює зниження врожайності.

Ключові слова: горох, норми висіву, елементи структури, врожайність.

\section{ВЛИЯНИЕ НОРМ ВЫСЕВА ГОРОХА НА ЕЛЕМЕНТЫ СТРУКТУРЫ И УРОЖАЙНОСТЬ ЗЕРНА}

\section{В. В. Лыхочвор, М. О. Андруико,}

Львовский национальный аграрный университет, г. Дубляны, Украина

Повышение нормы высева гороха сорта Мадонна с 0,9 млн/га до 1,4 млн/га привело к увеличению густоты растений перед уборкой с $70 \mathrm{um} . / \mathrm{m}^{2}$ до $90 \mathrm{~mm} . / \mathrm{s}^{2}$, или на $20 \mathrm{um} / \mathrm{m}^{2}$. Количество бобов на растени, соответственно уменьшилось с 4,8 до 4,5 шт., количество зерен в бобе с 6,9 до 6,1 ит., количество зерен из растения с 33 до 27,6 шт. Масса зерна с растения снизилась при загущении посевов с 9,60 г на варианте с высевом 0,9 млн/га до 7,05 г при высеве 1,4 млн/га, или на 2,55 г. Увеличение нормы высева сопровождалось также снижением массы 1000 зерен соответственно с 291,0 2 до 255,8 г. Оптимальной нормой высева гороха сорта Мадонна в условиях достаточного увлажнения западной Лесостепи Украинь является 1,0 и 1,1 млн/га. На этих вариантах урожайность зерна была высокой и составляла $6,52 \mathrm{~m} / 2$ а и $6,55 \mathrm{~m} / 2$. Такой уровень урожайности получен в результате рационального сочетания густоты растений перед уборкой (77 и $82 \mathrm{~mm} . / \mathrm{s}^{2}$ ) и повышения показателя массы зерна с одного растения к 8,96 г и 8,51 г.

Ключевые слова: горох, нормы высева, элементы структуры, урожайность.

\section{Вступ}

Високий потенціал урожайності сучасних сортів гороху може бути максимально реалізований при вирощуванні їх за технологіями, які передбачають комплексне застосування факторів інтенсифікації $[11,18,23]$.

Впровадження нових сортів гороху вусатого типу потребує експериментальних досліджень 3 метою оптимізації норми висіву з урахуванням умов зони вирощування. Для нормального росту і розвитку рослин потрібна відповідна площа живлення, за якої вони будуть мати достатньо поживних речовин, води і сонячної енергії для створення необхідної вегетативної маси й формування зерна [20, 22]. Шляхом збільшення чи зменшення площі живлення можна підвищити ефективність мінеральних добрив $[1,8]$. Продуктивність гороху найвища за оптимальної норми висіву, величина якої залежить від кліматичних умов, родючості грунту, попередника, удобрення, сорту, строків і способів сівби, якості насіння тощо [19].

На думку П. І. Грищука [4], науковці та виробничники й донині не мають єдиної думки щодо встановлення оптимальної норми висіву для польового ценозу гороху посівного. Велика кількість 


\section{СІЛЬСЬКЕ ГОСПОДАРСТВО. РОСЛИННИЦТВО}

повідомлень має значну давнину, виконана за різних регіональних умов, а комплексні дослідження 3 вивчення впливу норм висіву, способу сівби та погодних умов на формування врожаю зерна гороху в багатьох підзонах майже не проводилися.

Дослідники вказують на актуальність встановлення оптимальної норми висіву сортів гороху для певних грунтово-кліматичних умов $[3,15]$. Норма висіву повинна забезпечити оптимальну густоту посіву. Ї̈̈ встановлюють залежно від біологічних особливостей сорту і грунтово-кліматичної зони вирощування [13]. Вона коливається від 0,8 до 1,4 млн схожих насінин на гектар [5, 14]. У посушливих умовах висівають насіння менше, ніж у зоні достатнього зволоження більше [21].

Правильно вибрана норма висіву забезпечує високу адаптивну здатність, що дає змогу відновлювати до оптимального рівня процеси метаболізму післядії стресового фактору, що особливо важливо у зв'язку зі змінами і нестабільністю клімату. До основних властивостей, що визначають рівень адаптивності гороху відносяться високий збиральний індекс, тип росту стебла, дружне достигання, стійкість проти хвороб, стійкість до осипання, висока потенціальна врожайність $[9,16]$.

Оптимальна густота рослин і забезпечення елементами живлення є найважливішими умовами, від яких залежить продуктивність посівів. Тому важливо вивчити, як саме різні норми висіву впливають на густоту та продуктивність рослин, а також на процеси формування елементів структури врожайності. Оптимальна густота рослин перед збиранням є критерієм правильності встановлення норми висіву під час сівби, що визначається шляхом проведення відповідних польових дослідів. За різних грунтово-кліматичних умов норма висіву може значно впливати на реалізацію потенціалу врожайності гороху [2]. Потрібно враховувати, що в різних зонах оптимальна густота рослин може коливатися в широких межах і не залишається постійною впродовж вегетації.

Мета досліджень: виявити особливості росту, розвитку та формування елементів продуктивності сортів гороху через оптимізацію норм висіву насіння при вирощуванні за інтенсивною технологією в умовах достатнього зволоження західного Лісостепу.

Завдання дослідження: вивчити вплив норм висіву на густоту рослин, елементи структури врожаю та рівень урожайності зерна гороху сорту Мадонна.

\section{Матеріали і методи досліджень}

Дослідження проводили впродовж 2017-2019 рр. на дослідному полі Львівського національного аграрного університету на темно-сірому опідзоленому легкосуглинковому грунті. Вміст загального гумусу - за методом Тюріна в модифікації Нікітіна (ДСТУ 4289:2004) середній і становить 2,2-2,3 \%. Реакція грантового розчину слабокисла, pH сольове - потенціометрично (ДСТУ ISO 10390-2007) 6,06,1. Легкогідролізований азот за методом Корнфілда (ДСТУ 7863:2015) становить 101-112 мг/кг грунту і за ступенем забезпечення відноситься до класу низьких. Рухомі сполуки фосфору за Чириковим (ДСТУ 4115-2002) 124-128 мг/кг грунту, обмінний калій за Чириковим (ДСТУ 4115-2002), 95110 мг/кг грунту. Відповідно групуванню грунтів за вмістом рухомого фосфору та калію ці два елементи відносяться до підвищеного ступеня забезпеченості.

Польові досліди проводили відповідно до загальноприйнятої методики Б. А. Доспехова [7]. Загальна площа елементарної ділянки складала $60 \mathrm{~m}^{2}$, облікова площа ділянок - $50 \mathrm{~m}^{2}$, повторність досліду триразова, розміщення ділянок - систематизоване. Схему досліду наведено в таблиці 1.

Вирощували горох за інтенсивною технологією, яка передбачала дотримання усіх іï елементів. Мінеральні добрива вносили за схемою: $\mathrm{P}_{60} \mathrm{~K}_{60}+\mathrm{N}_{60}+\mathrm{Mg}_{20}+\mathrm{S}_{30}+$ Інтермаг бобові (2 л/га). Протруювали насіння протруйником Максим XL (флудиоксоніл, 25 г/л + металаксил-M, 10 г/л) 3 нормою 1,0 л/т та обробляли бактеріальним добривом Оптімайз Пульс. Для боротьби 3 дводольними та злаковими бур'янами у фазі 3-х трійчастих листків вносили гербіцид Пульсар 40 (імазамокс, 40 г/л) 3 нормою 1 л/га. Навесні для захисту від хвороб двічі посіви обприскували фунгіцидами: у фазі початку бутонізації вносили фунгіцид Фокс (трифлоксистробін, 150 г/л + протіоконазол, 175 г/л) у нормі 0,5 л/га, та у фазі цвітіння препарат Амістар Екстра (ципроконазол, 80 г/л + азоксистробін, 200 г/л) у нормі 0,5 л/га. Проти шкідників двічі використовували інсектициди: Фастак (альфа-циперметрин, 100 г/л) у фазі початку цвітіння 3 нормою 0,20 л/га та Енжіо (тіаметоксам, 141 г/л + лямбдацигалотрин, 106 л/га) у фазі цвітіння з нормою 0,18 л/га.

Для розв'язання поставлених завдань було проведено комплекс спостережень, обліків та аналізів. Визначення густоти рослин проводили за «Методикою державного сортовипробування сільськогос- 


\section{СІЛЬСЬКЕ ГОСПОДАРСТВО. РОСЛИННИЦТВО}

подарських культур (2001)». Облік структури врожаю проводили шляхом аналізу пробних снопів. Урожайність встановлювали шляхом обмолоту зерна у фазі повної стиглості методом суцільного обмолоту комбайном SAMPO-500.

\section{Результати досліджень та їх обговорення}

Густота рослин на одиниці площі є одним 3 найважливіших елементів структури врожаю. Під впливом норм висіву, незважаючи на зниження польової схожості на варіантах з вищою нормою висіву, густота рослин у фазі сходів була суттєво більшою за вищих норм висіву.

На варіанті 3 нормою висіву 0,9 млн/га вона становила в середньому за три роки 73 рослини/м ${ }^{2}$ (табл. 1). Збільшення норми висіву до 1,0 млн/га призвело до зростання густоти рослин у фазі сходів

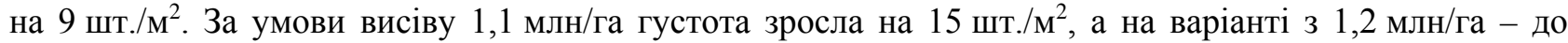
94 шт./м².

Найбільшою густота рослин гороху у фазі сходів, як і очікувалося, була за норми висіву 1,3 млн/га

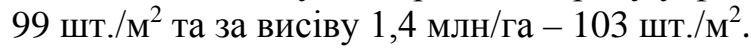

Густота рослин гороху перед збиранням теж збільшувалась на варіантах з вищою нормою висіву. Якщо при висіві 0,9 млн/га вона становила $70 ш \mathrm{~m} / \mathrm{m}^{2}$, то за максимальної норми висіву зросла до 90 шт./ ${ }^{2}$, або на 20 шт./м². Необхідно відмітити, що збільшення норми висіву на 0,1 млн/га означає збільшення на 10 рослин/м². Якщо на першому варіанті додаткових 10 насінин прибавили 7 рослин перед збиранням, то за висіву 1,4 млн/га - лише одну рослину. Тобто з висіяних 90 насінин на м² залишилося 70 рослин $/ \mathrm{m}^{2}$, а за висіву 140 н/ $\mathrm{m}^{2}$ - залишилося до збирання 90 рослин/ $/ \mathrm{m}^{2}$. Це пояснюється зниженням польової схожості та рівня виживання рослин за вищих норм висіву.

\section{1. Густота рослин гороху сорту Мадонна у фазі сходів та перед збиранням}

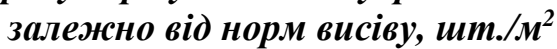

\begin{tabular}{|c|c|c|c|c|c|c|c|}
\hline $\begin{array}{c}\text { Норма висіву, } \\
\text { млн/га }\end{array}$ & 2017 p. & 2018 p. & 2019 р. & Середнє & ++- & \multicolumn{2}{|c|}{ Приріст від 0,1 млн/га } \\
\hline 0,9 & $72 / 69$ & $75 / 72$ & $73 / 69$ & $73 / 70$ & - & - & сходи \\
\hline 1,0 & $80 / 74$ & $83 / 79$ & $82 / 78$ & $82 / 77$ & $9 / 7$ & 9 & 7 \\
\hline 1,1 & $87 / 81$ & $89 / 84$ & $88 / 81$ & $88 / 82$ & $15 / 12$ & 6 & 5 \\
\hline 1,2 & $92 / 84$ & $96 / 89$ & $95 / 85$ & $94 / 86$ & $21 / 16$ & 6 & 4 \\
\hline 1,3 & $97 / 88$ & $101 / 91$ & $100 / 88$ & $99 / 89$ & $26 / 19$ & 5 & 3 \\
\hline 1,4 & $99 / 87$ & $106 / 92$ & $105 / 91$ & $103 / 90$ & $30 / 20$ & 4 & 1 \\
\hline Середнє за рік & $88 / 80$ & $92 / 84$ & $90 / 82$ & & & & \\
\hline
\end{tabular}

Примітки: * чисельник - густота рослин у фазі сходів, знаменник - густота рослин перед збиранням.

Отже, зростання норми висіву з 0,9 млн/га до 1,4 млн/га призвело до збільшення густоти рослин у

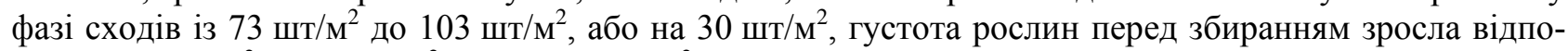

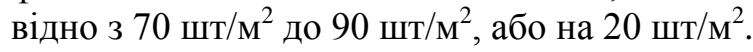

Під впливом норм висіву змінювалися також інші елементи структури врожаю. Основні елементи структури врожаю, такі як кількість квіток, бобів і насінин, маса насіння тощо, прямо пов'язані з формуванням зернової продуктивності. На думку М. І. Кондратенка [12], важливо сформувати оптимальні показники структури врожаю, оскільки між кількістю бобів на рослині, кількістю зерен на рослині, масою зерна з рослин та врожайністю існує пряма кореляційна залежність.

За даними Інституту землеробства НААН, кількість сформованих бобів мала значну варіабельність та виражала рівень продуктивності культури, в середньому цей показник знаходився в межах 6,4-7,8 шт. Найнижчий рівень формування бобів відмічається в сорту Чекбек [6].

Кількість бобів на рослині в наших дослідженнях зменшувалася на варіантах із більшою нормою висіву. За висіву 0,9 млн/га на рослині було 4,8 шт., при висіві 1,4 млн/га - знизилась до 4,5 бобу на рослину (табл. 2). Кількість зерен у бобі теж знизилась з 6,9 шт. за норми висіву 0,9 млн/га до 6,1 шт. при висіві 1,4 млн/га. Загущення посівів спричинило зменшення кількості зерен 3 рослини з 33,0 шт. на варіанті з нормою висіву 0,9 млн/га до 27,6 шт. за висіву 1,4 млн/га, тобто на 5,4 шт. 


\section{СІЛЬСЬКЕ ГОСПОДАРСТВО. РОСЛИННИЦТВО}

\section{2. Показники елементів структури врожаю гороху сорту Мадонна залежно від норм висіву, (середнє за 2017-2019 рр.)}

\begin{tabular}{|c|c|c|c|c|c|}
\hline $\begin{array}{c}\text { Норма висіву, } \\
\text { млн./га }\end{array}$ & $\begin{array}{c}\text { Кількість бобів } \\
\text { на 1 рослину, } \\
\text { шт }\end{array}$ & $\begin{array}{c}\text { Кількість зерен } \\
\text { на 1 рослину, } \\
\text { шт }\end{array}$ & $\begin{array}{c}\text { Кількість зерен } \\
\text { у бобі, шт }\end{array}$ & $\begin{array}{c}\text { Маса } \\
1000 \text { зе- } \\
\text { рен, г }\end{array}$ & $\begin{array}{c}\text { Маса зерна з } \\
\text { 1 рослини, г }\end{array}$ \\
\hline 0,9 & 4,8 & 33,0 & 6,9 & 291,0 & 9,60 \\
\hline 1,0 & 4,8 & 32,0 & 6,7 & 280,0 & 8,96 \\
\hline 1,1 & 4,8 & 31,2 & 6,5 & 272,8 & 8,51 \\
\hline 1,2 & 4,6 & 29,0 & 6,3 & 266,5 & 7,73 \\
\hline 1,3 & 4,5 & 28,0 & 6,2 & 260,8 & 7,30 \\
\hline 1,4 & 4,5 & 27,6 & 6,1 & 255,8 & 7,05 \\
\hline
\end{tabular}

За даними О. В. Ільєнка [10], кількість зерен у бобі за норми висіву 1,8 млн/га була найменшою i залежно від фону добрив становила 4,4-4,9 шт., а за норми висіву 1,2 млн/га - найбільшою 6,3-6,9 шт.

Ще більше змінювались під впливом норми висіву маса зерна з рослини та маса 1000 зерен. Якщо на першому варіанті з мінімальною густотою рослин, маса зерна з рослини становила 9,60 г, то при загущенні посівів за норми висіву 1,4 млн/га вона знизилася до 7,05 г, або на 2,55 г. Урожайність гороху різко не знижувалася лише внаслідок зростання іншого важливого елементу структури врожаю - густоти рослин. Маса 1000 зерен теж закономірно знижувалася при загущенні посівів. За норми висіву 0,9 млн/га вона становила 291,0 г, а на варіанті з висівом 1,4 млн/га зменшилась до 255,8 г, або на 35,2 г. Найвищою біологічна врожайність (6,98 т/га) формувалась за оптимального поєднання показників густоти рослин і маси зерна з рослини на варіанті з нормою висіву 1,1 млн/га.

Подібні результати одержані і в інших дослідженнях. За збільшення норми висіву на 0,5 млн/га (з 1,0 до 1,5 млн/га) зменшувалась кількість бобів на рослині, кількість зерен з однієї рослини, маса 1000 зерен, проте норма висіву не впливала на кількість зерен у бобі [17].

Отже, норми висіву мали істотний вплив на показники структури врожаю гороху. При зростанні норми висіву насіння з 0,9 млн/га до 1,4 млн/га кількість бобів на рослині зменшилась 3 4,8 до 4,5 шт., кількість зерен у бобі з 6,9 до 6,1 шт., кількість зерен з рослини з 33 до 27,6 шт. Основний елемент продуктивності, маса зерна з рослини знизилась при загущенні посівів, відповідно, з 9,70 г до 7,05 г, а маса 1000 зерен - $з$ 291,0 г до 255,8 г.

У експериментальних польових дослідженнях виявлено залежність зернової продуктивності гороху сорту Мадонна від метеорологічних умов року та норм висіву насіння. Найкращі гідротермічні умови для формування врожайності зерна гороху склалися 2017 року.

Урожайність у перший рік досліджень в середньому за досліджуваними нормами висіву становила 6,87 т/га. 2018 року урожайність знизилась до 6,25 т/га, або на 0,62 т/га, а 2019 року була найменшою - 6,00 т/га, що нижче на 0,87 т/га, порівняно з 2017 роком (табл. 3) Зменшення врожайності 2018 року можна пояснити недостатньою кількістю опадів у квітні (-18 мм від середньої багаторічної норми) та травні (-18 мм) і надмірним зволоженням у червні (+69 мм) та липні (+35 мм). 2019 року негативний вплив на рівень урожайності викликаний перезволоженням у травні (+92 мм до норми).

Урожайність зерна гороху змінювалась не лише залежно від умов року, але й під впливом досліджуваних норм висіву насіння. За норми висіву 0,9 млн/га в середньому за три роки урожайність становила 6,34 т/га. При підвищенні норми висіву до 1,0 та 1,1 млн/га урожайність зросла і була найвищою, відповідно 6,52 та 6,55 т/га, що вище від норми висіву 0,9 млн/га на 0,18 та 0,21 т/га (табл. 3).

Подальше збільшення норми висіву до 1,$2 ; 1,3$ та 1,4 млн/га призводило до закономірного зменшення врожайності. На варіанті з нормою висіву 1,4 млн/га загущення посівів спричинило зниження врожайності до 6,15 т/га, що на 0,40 т/га (6,11 \%) менше порівняно з варіантом висіву 1,1 млн/га.

Отже, оптимальною нормою висіву гороху сорту Мадонна в умовах достатнього зволоження західного Лісостепу України є 1,0 та 1,1 млн/га. 


\section{СІЛЬСЬКЕ ГОСПОДАРСТВО. РОСЛИННИЦТВО}

\section{3. Урожайність зерна гороху сорту Мадонна залежно від норм висіву, $\mathrm{m} / 2$ а}

\begin{tabular}{|c|c|c|c|c|c|c|}
\hline \multirow{2}{*}{$\begin{array}{c}\text { Норма висіву, } \\
\text { млн/га }\end{array}$} & $2017 \mathrm{p}$ & $2018 \mathrm{p}$ & $2019 \mathrm{p}$ & $\begin{array}{c}\text { Середнє за три } \\
\text { роки }\end{array}$ & Зниження урожаю, $+/-$ \\
\hline 0,9 & 6,85 & 6,21 & 5,95 & 6,34 & $-0,18$ & $-2,75$ \\
\hline 1,0 & 7,05 & 6,38 & 6,12 & $\mathbf{6 , 5 2}$ & $-0,03$ & $-0,46$ \\
\hline 1,1 & 7,10 & 6,40 & 6,15 & $\mathbf{6 , 5 5}$ & - & - \\
\hline 1,2 & 6,90 & 6,25 & 6,04 & 6,40 & $-0,15$ & $-2,29$ \\
\hline 1,3 & 6,75 & 6,20 & 5,92 & 6,29 & $-0,26$ & $-3,97$ \\
\hline 1,4 & 6,58 & 6,07 & 5,80 & 6,15 & $-0,40$ & $-6,11$ \\
\hline Середнє по року $^{2}$ & 6,87 & 6,25 & 6,00 & $\mathbf{6 , 3 8}$ & & \\
\hline НІР $_{0,5}, \mathrm{~T} /$ га & 0,16 & 0,16 & 0,12 & & & \\
\hline
\end{tabular}

\section{Висновки}

Підвищення норми висіву з 0,9 млн/га до 1,4 млн/га призвело до збільшення густоти рослин перед

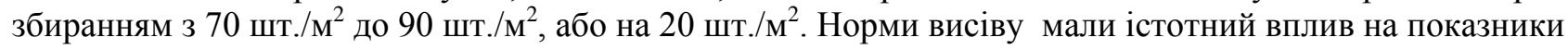
структури врожаю гороху. При зростанні норми висіву насіння з 0,9 млн/га до 1,4 млн/га кількість бобів на рослині зменшилась з 4,8 до 4,5 шт., кількість зерен у бобі з 6,9 до 6,1 шт., кількість зерен 3 рослини 333 до 27,6 шт. Основний елемент продуктивності, маса зерна з рослини знизилась при загущенні посівів, відповідно, з 9,60 г до 7,05 г, а маса 1000 зерен - $з$ 291,0 г до 255,8 г.

Оптимальною нормою висіву гороху сорту Мадонна в умовах достатнього зволоження західного Лісостепу України $€$ 1,0 та 1,1 млн/га. Збільшення і зменшення норми висіву спричинює зниження врожайності.

Перспективи подальщих досліджень. Важливо уточнити норми висіву нових сортів гороху для конкретних грунтово-кліматичних умов. Впровадження високоврожайних інтенсивних технологій вирощування, які базуються на ширшому використанні мінеральних добрив та засобів захисту рослин, теж потребуватиме оптимізації норм висіву.

\section{References}

1. Andrushko, M. O., Lykhochvor, V. V., \& Andrushko, O. M. (2019). Urozhaynist zerna gorohu zalezhno vid elementiv sistemi udobrennya. Visnik Lvivskogo Natsionainogo Agrarnogo Universitetu: Agronomiya, 23, 67-71. doi: 10.31734/agronomy2019.01.067 [In Ukrainian].

2. Vasilenko, A. O., Bezugliy, I. M., Shevchenko, L. M., Shtelma, A. M., Glyantsev, A. V., \& Ischenko N. K. (2018). Vpliv abIotichnih chinnikiv na realizatsiyu potentsialu vrozhaynosti sortiv gorohu. Selektsiya i Nasinnitstvo, 3,- 35-44. doi: 10.30835/2413-7510.2018.134356 [In Ukrainian].

3. Gyrka, A., Tkalich, I., Sydorenko, J., Bochevar, O., \& Il’ienko, O. (2018). Actual aspects of technique of growing pease in conditions of Northern Steppe of Ukraine. Visnyk Agrarnoi Nauky, 96 (2), 31-35. doi: 10.31073/agrovisnyk201802-05.

4. Grischuk, P. I. (2017).Vpliv schilnostI agrotsenozu gorohu posivnogo na yogo zernovu produktivnist. Visnik Umanskogo Natsionalnogo Universitetu Sadivnitstva, 2, 48-51 [In Ukrainian].

5. Grischuk P. I. (2016). Osoblivosti vstanovlennya kilkisnoyi normi visivu gorohu posivnogo. Zernobobovi kulturi ta soya dlya stalogo rozvitku agrarnogo virobnitstva Ukrayini. Materiali mizhnarodnoyi naukovoyi konferentsiyi. Vinnitsya: Dilo [In Ukrainian].

6. Dvoretska, S. P., Ryabokin, T. M., \& Efimenko, G. M. (2014). Osoblivosti formuvannya elementiv produktivnosti roslin gorohu zalezhno vid rivnya Intensifikatsiyi tehnologiyi viroschuvannya kulturi. Zbirnik Naukovih Prats "NNTS Institut Zemlerobstva NAAN", 3, 56-66 [In Ukrainian].

7. Dospeho, B. A. (1985). Metodika polevogo opyita (s osnovami statisticheskoy obrabotki rezultatov issledovaniy). Moskva: Kolos [In Russian].

8. Eremko, L. S., Gangur, V. V., Kirichok, O. O., \& Sokirko, D. P. (2019). Mineralne zhivlennya yak faktor pidvischennya fotosintetichnoyi produktivnosti i urozhaynosti posiviv gorohu. Visnik Poltavskoyi Derzhavnoyi Agrarnoyi Akademiyi, 3, 50-56. doi: 10.31210/visnyk2019.03.06 [In Ukrainian].

9. Zhuykov, O. G., \& Lagutenko, K. V. (2017). Goroh posivniy v Ukrayini - stan, problemi, perspektivi. Tavriyskiy Naukoviy Visnik: Zemlerobstvo, Roslinnitstvo, Ovochivnitstvo ta Bashtannitstvo, 98, 65-70 [In Ukrainian]. 
10. Ilenko, O. V. (2013). Formuvannya vrozhaynosti gorohu vusatogo morfologichnogo tipu pid vplivom dobriv ta norm visivu nasinnya v umovah pivnIchnogo Stepu. Byuleten Institutu Silskogo Gospodarstva Stepovoyi Zoni NAAN Ukrayini, 4, 33-37 [In Ukrainian].

11. Kaminskiy, V. F., \& Dvoretska, S. P. (2003). Efektivnist modeley tehnologiyi viroschuvannya gorohu zalezhno vid rIvnya yih Intensifikatsiyi. Zbirnik Naukovih Prats Umanskogo Derzhavnogo Agrarnogo Universitetu, 734-737 [In Ukrainian].

12. Kondratenko, M. I. (2015). Formuvannya adaptivnosti oznak zernovoyi produktivnosti kolektsiynih zrazkiv gorohu posivnogo riznih morfotipiv $\mathrm{v}$ umovah pravoberezhnogo Lisostepu Ukrayini. Kormi $i$ Kormovirobnitstvo, 81, 21-30 [In Ukrainian].

13. Lykhochvor, V. V., Petrichenko, V. F., \& Ivaschuk, P. V. (2008). Zernovirobnitstvo. LvIv: NVF "Ukrayinski tehnologiyi" [In Ukrainian].

14. Lykhochvor, V. V., Prots, R. R., Dolezha, I. Ya. (2003). Goroh. LvIv: NVF"Ukrayinski tehnologiyi" [In Ukrainian].

15. Petrychenko, V., \& Lykhochvor, V. (2019). Plant growing. New technologies for field crops cultivation: a textbook. doi: 10.31073/roslynnytstvo5vydannya.

16. Telekalo, N. V. (2019). Vpliv kompleksu tehnologichnih priyomiv na viroschuvannya gorohu posivnogo. Silske gospodarstvo ta lisivnitstvo, 13, 84-93 [In Ukrainian].

17. Harchenko, O. V., Prasol, V. I., Ilchenko, O. V. (2009). Agroekologichne ta ekologichne obgruntuvannya zhivlennya silskogospodarskih kultur. Sumy: Universitetska kniga [In Ukrainian].

18. Cherenkov, A. V., Klisha, A. I., Girka, A. D., \& KulinIch, O. O. (2014). Zernobobovi kulturi: suchasni tehnologiyi viroschuvannya: monografiya. Dnipropetrovsk: Aktsent PP [In Ukrainian].

19. Lenssen, A. W., Sainju, U. M., Jabro, J. D., Allen, B. L., \& Stevens, W. B. (2018). Dryland Pea Production and Water Use Responses to Tillage, Crop Rotation, and Weed Management Practice. Agronomy Journal, 110 (5), 1843-1853. doi: 10.2134/agronj2018.03.0182.

20. Khan, T. N., Meldrum, A., \& Croser, J. S. (2016). Pea Overview. Reference Module in Food Science. doi: 10.1016/b978-0-08-100596-5.00037-8

21. Kindie, Y., Bezabih, A., Beshir, W., Nigusie, Z., Asemamaw, Z., Adem, A., Antenh Adem, Tebabele, B., Kebede, G., Alemayehu, T., \& Assres, F. (2019). Field Pea (Pisum sativum L.) Variety Development for Moisture Deficit Areas of Eastern Amhara, Ethiopia. Advances in Agriculture, 2019, 1-6. doi: 10.1155/2019/1398612.

22. Tulbek, M. C., Lam, R. S. H., Wang, Y. C., Asavajaru, P., \& Lam, A. (2017). Pea. Sustainable Protein Sources, 145-164. doi: 10.1016/b978-0-12-802778-3.00009-3.

23. Vann, R. A., Reberg-Horton, S. C., Castillo, M. S., Mirsky, S. B., \& McGee, R. J. (2018). Winter Pea Cultivar/Breeding Line Screening for Grain Crop Potential in the Southeastern United States. Agronomy Journal, 110 (4), 1217-1225. doi: 10.2134/agronj2017.10.0594.

Стаття надійшла до редакції 27.11.2019 р.

Бібліографічний опис для цитування:

Лихочвор В. В., Андрушко М. О. Вплив норм висіву гороху на елементи структури та врожайність зерна. Вісник ПДАА. 2019. № 4. С. 51-57.

(C) Лихочвор Володимир Володимирович, Андрушко Микола Олегович, 2019 